\title{
The Bantu Presbyterian Church in South Africa and Ecumenism, 1940-1999
}

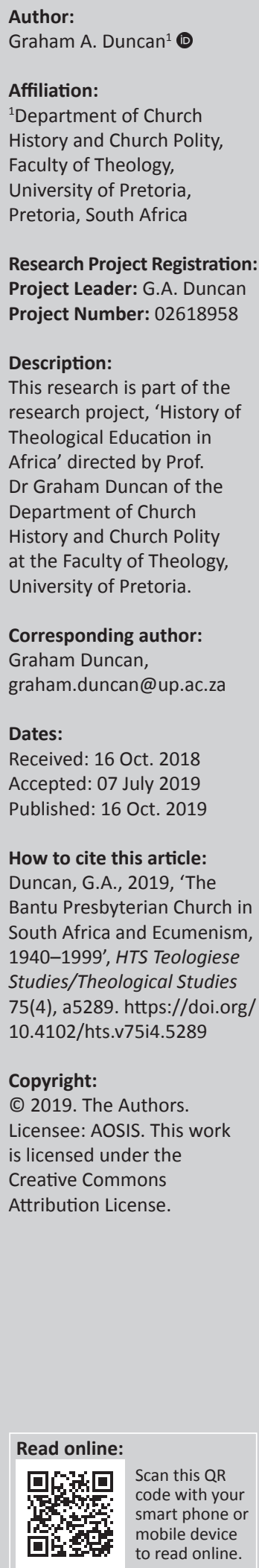

From 1940, ecumenical developments in the Presbyterian/Congregational corpus in Southern Africa became more tortuous and complex, with an expansion of the number of denominations involved in union negotiations to include the Bantu Presbyterian Church of South Africa (BPCSA, from 1979 the Reformed Presbyterian Church in Southern Africa, RPCSA), the Congregational Union of South Africa, later the United Congregational Church of South Africa, the Presbyterian Church of Southern Africa and the Tsonga Presbyterian Church (TPC, later the Evangelical Presbyterian Church of South Africa, EPCSA). The problem statement centres around the complex situation that despite substantial similarities in doctrine, liturgy and polity, as well as involvement in the Church Unity Commission and the South African Council of Churches, the union proved to be elusive. The aim of this article is to investigate the dynamics of the developing relationships and hindrances to closer relationships in the wider South African context. This study is conducted from the perspective of the BPCSA and RPCSA, and the methodology is based predominantly on archival research.

Keywords: Bantu (Reformed) Presbyterian Church of South Africa; The Congregational Union of South Africa; The Presbyterian Church of South Africa; Tsonga (Evangelical) Presbyterian Church of Southern Africa; Churches of European Origin.

\section{Introduction}

This study centres around the situation among a group of Churches of European Origin (CEO) which engaged in discussions focussed on achieving a united Reformed denomination in South Africa from the 1940s until 1999 when the Reformed Presbyterian Church in Southern Africa (RPCSA) entered union with the Presbyterian Church of Southern Africa (PCSA) to form the Uniting Presbyterian Church in Southern Africa. Despite substantial similarities in doctrine, liturgy and polity, as well as involvement in the Church Unity Commission (CUC) and the South African Council of Churches, union proved to be elusive for most of the 20th century (De Gruchy 1997:157). The aim of this article is to investigate the dynamics of the developing relationships and the pervasive 'political' hindrances to closer relationships in the wider South African context. This study is conducted from the perspective of the Bantu Presbyterian Church of South Africa (BPCSA)/RPCSA, and the methodology is based predominantly on archival research.

\section{Background}

The Faith and Order Conference (of what was to become an integral part of the World Council of Churches in 1948) was held in Edinburgh in 1937 (Best 1992:30). It noted three ecumenical models - cooperative unity, mutual recognition and organic union. In the South African context, the first worked intermittently; the second was a distinct reality and the third at this stage was seemingly unattainable. Yet, Xapile (1999) was confident that:

$[\ldots U]$ nion was possible. It was necessary in order that both blacks [sic] and white Christians stand united not only as regards ecclesial matters but also as a united front against apartheid. Some members of the BPC were not convinced that a united church would help them towards their goal. They wondered if it would not add to their suffering. Sadly, those who held this view won. The people of God, the church, had to wait for politics to dictate how they should do things. (p. 99)

This was the point which was reached after a number of years of striving for a form of organic unity within Presbyterianism in South Africa where, in addition to ecclesiastical factors, political and/ or racial issues became and remained an obstacle or barrier to union (Duncan 2017, 2018). 


\section{Onward Christian soldiers}

The 1941 General Assembly of the BPCSA remitted the matter of union to the next (1942) assembly and distributed the draft basis of union to commissioners to Assembly (BPCSA 1942:47). The 1942 General Assembly resolved that (BPCSA 1942):

[T] his matter be allowed to remain on the table until such time as the Bantu Presbyterian Church is sufficiently established to take its full share in such matters as Union with other Churches. (p. 23)

Clearly, the BPCSA was not going to be coerced into any union before it felt it had reached a stage of sufficient maturity to play its full part in any union. It was still a young church with a need to develop its own distinctive ethos as a black Presbyterian church. In 1944, the General Assembly received a notice of motion: 'That the Assembly review minute 1669 (BPCSA 1942:23) with the object of opening negotiations with the Presbyterian Church of South Africa' (BPCSA 1944:13). This matter was not dealt with and the matter remained dormant. This particular proposed negotiation had been on and off the agenda since before the formation of the PCSA in 1987. One of the issues was a perennial problem in union negotiations that it was normally the enthusiasts for union who become involved in negotiations and they are prepared to move at a quicker pace than those who are indifferent or opposed to church union. In addition, racism had been a constant issue which deterred both sides from union.

In 1956, a decision was reached to engage with the PCSA, taking account of '(a) The competition between the two Churches, (b) The constitutions of the two Churches' (BPCSA 1956:34). During the following year, the PCSA presented 'minimal terms for union', and it was agreed to prepare a response (BPCSA 1958:35). It appeared as if the BPCSA was serious in its intent for union as it wanted to resolve issues which had been contentious for some years. At the same Assembly, both the Free Church of Scotland in South Africa and the Presbyterian Church of Africa (PCA) expressed interest in union with the BPCSA (BPCSA 1958:35-36). With regard to (a), there were serious outstanding issues relating to comity in the urban areas. In addition, there were differing views of the status of black ministers. In the PCSA, black ministers in the missions were not awarded the same status as white ministers. This was intolerable for the BPCSA which supported full parity in the ordained ministerial office. This arose out of the concern in the BPCSA that in the PCSA there were differentials in ministry, mainly subordinating the black ministers to inferior status. Discussions continued, and in 1959, the Church of the Province (Anglican) requested a meeting with representatives of the BPCSA and PCSA to discuss 'a clearer understanding between the churches and that the Union for which we all pray might be forwarded' (BPCSA 1959:45). This was a prelude to the formation of the CUC in 1968. The BPCSA acceded to this request. The PCSA received a report under its African Missions Committee in 1959 that the Tsonga Presbyterian Church might be prepared to join with the BPCSA in talks regarding possible union
(PCSA 1959:76). This was a period in which ecumenism in terms of church union was enthusiastically embraced by its promoters. However, the PCSA espoused two systems for mission work. The mission to black ministers came under the jurisdiction of the African Missions Committee, while the mission to white ministers was the responsibility of the Church Extension Committee.

By 1960, matters had advanced apace, and the BPCSA agreed 'to proceed with the negotiations towards full union on the basic principle of the equal status of all ministers, elders and members'. An earlier decision to attempt 'a five year period of union at Presbytery level and separate Assemblies' was dismissed (BPCSA 1960:22). This Assembly also agreed to continue to negotiate with the (PCA - the body which seceded from the Scottish Mission in 1898). A significant development occurred in 1962 with the agreement that in a united church there would be equality of status in the ordained ministry (PCSA 1962:217). Thereafter, there was little substantial progress except that in 1964, the BPCSA General Assembly recommended that contact should be made with the sister congregations of the PCSA and the Tsonga Presbyterian Church (TPC) (BPCSA 1964:19).

However, the progress was intermittent. The PCSA sent what amounted to an ultimatum to the 1965 General Assembly of the BPCSA, informing them that if they did not ratify the resolution on union, they would proceed with negotiations with the TPC, 'but assures the BPC in this event its return to the negotiations will be welcomed at any time it feels able to do so' (BPCSA 1965:25; PCSA 1965:42). The BPCSA responded to the frustration of the PCSA with a resolution assuring the PCSA (BPCSA 1965):

[T] hat the proposed church union must be one of depth which involves a real conviction of oneness in Christ and not merely an association for the sake of administrative efficiency. (p. 29)

The issue related to property issues in the Draft Basis of Union (paragraph 3 of Schedule J, p. 42) which the PCSA viewed as 'a matter of detail' (PCSA 1965:222-223). The BPCSA believed differently. For them, it was unacceptable that white congregations be able to hold their own title deeds, while the black church agreed to their properties being held by the General Trustees of the denomination. This was exacerbated by different perceptions of the nature of land ownership in the black community where land was held in trust for the entire community. The PCSA had a more individualistic approach both individually and as individual congregations and viewed this matter 'either as a misconception of the situation or on the premises which are quite unknown to us' (PCSA 1965:223). This arose out of the situation whereby PCSA congregations prior to its formation in 1897 were independent having no superior bodies to whom they were subject and, therefore, they held their own title deeds. This was the case even after 1897. The BPCSA had been part of the Scottish Mission, and all of their properties were vested in the name of the trustees of the denomination. Nonetheless, the Draft Basis of Union was sent down to 
presbyteries and congregations with the commendation to work towards closer cooperation.

At the same Assembly, it was reported that Presbyterian (BPCSA, PCSA and TPC) conversations with Anglicans had progressed to the stage of the formulation of a Statement of Belief and a proposed Covenant. It was further agreed to engage in internal discussion for a period of 3 years. The two main points of discussion were the role of the episcopacy and inter-communion (BPCSA 1965:33) both of which were fractious historical issues. In 1966, the BPCSA resolved 'to take such steps as its constitution requires to secure the approval of the Bantu Presbyterian Church to the Draft Basis of Union' (BPCSA 1966:34). This was indeed a significant step forward. The following year, it was noted that of the seven presbyteries, four accepted the basis of union, while one rejected it with two not replying. The status of the laity was raised with the PCSA (BPCSA 1967:41) because of the different views of the role of elders. The draft Basis of Union was again sent down to presbyteries in 1968 (BPCSA 1968:40). Comments received were remitted to the Unions Committee to be reported on in 1970 (BPCSA 1969:31). In 1970 (BPCSA 1970):

By 35 votes to 12 the Assembly accepted the Basis of Union as in the printed booklet and sends down to Presbyteries the Final Basis of Union for approval or otherwise and report to the next Assembly. The Rt Rev JY Hliso entered his dissent. (p. 45)

The status of this dissent is unclear as the Moderator of General Assembly has no deliberative vote and hence no right of dissent. However, Hliso was a powerful personality in the BPCSA and a well-known opponent of union largely as the result of his work in Port Elizabeth and Cape Town where he had encountered hostility from the PCSA for infringing a supposed agreement that the PCSA would work in urban areas, while the BPCSA would minister in rural areas. This had serious implications for the membership and finances of both denominations and was largely to the detriment of the BPCSA. While four presbyteries voted in favour of union in 1971, there was a general lack of unanimity. Over a third of the Assembly voted for a deferral of a final decision and 'the Assembly, realising the unhappy atmosphere' again remitted the matter to presbyteries for another year. Visits were again to be paid to congregations by the General Secretary to assess their views on union (BPCSA 1971:33-34). The PCSA had voted in favour of union by a substantial majority in 1970 (PCSA 1970:109). This had been the traditional stance of the PCSA for many years. They sought union in the hope of forming a united body in Presbyterianism. The problem the BPCSA had with this was that the black congregations of the PCSA were missions of white congregations with no independent status, while all the BPCSA congregations had full status. This was because 'The white Presbyterians gradually developed their own mission work and so became multiracial in principle, though ... seldom in practice ...' (De Gruchy 2005:16). The black BPCSA was not prepared to give up its privileges and status.
Concurrently, events were proceeding apace in the CUC (formed in 1968) (Wing 1990:1) of which the BPC was a member along with the PCSA, the Tsonga Presbyterian Church, the Methodist Church of South Africa, the Church of the Province (Anglican) and the United Congregational Church. Villa-Vicencio (1988:17) wrongly excludes the BPC and TPC. Although they are black churches, they are CEOs. He also wrongly claims that they were dependent on settler churches as they were mission churches sponsored from Scotland and Switzerland (Villa-Vicencio 1988:29). However, he is only partially correct in his assertion that 'given the diverse nature of their membership, [they] can only experience further disintegration of the limited internal cohesion they have built up over the years' (Villa-Vicencio 1988:137). The situation is that the CUC churches have remained resilient against internal disputes regarding theological difference (e.g. the development of liberation and black theology, language and style of worship). Despite this, they have remained united as they reflect substantial racial and cultural diversity [as] part of the very fabric and significance (De Gruchy 1979:86). The only exception is the EPCSA (see below) (BPCSA 1972).

\section{In 1972, the BPCSA General Assembly affirmed the CUC} Declaration of Intention:

Believing that a union of churches in Christ involved a full and deep fellowship

Among men [sic] of all races and a brotherhood [sic] crossing all barriers of race,

And believing that there is not at the moment sufficient evidence of brotherhood even in the congregations of our different Presbyterian Churches in the various places where they exist side by side,

And believing that justice and peace among all the peoples of this land are supremely important and that our churches have not given sufficient attention to these matters,

And believing that fellowship among Christians of all races is a necessary preliminary to a meaningful structural union

Assembly resolves:

To seek a deeper fellowship and brotherhood among Churches at all levels ... (p. 29)

This was sent down to Presbyteries for study and comment prior to sending down the Plan of Union with encouragement to participate in local initiatives (BPCSA 1972:30). This step to improve relations indicates that the BPCSA was not against union in principle (it had also engaged the Anglicans), but it also indicates that in the particular case of union with the PCSA, there were unresolved racial issues that appeared to be intractable. Later in 1972, the PCSA approached the BPC with a request for comments on their proposal to relocate their General Assembly office in Johannesburg. The BPC was of the opinion that the office should remain in the centre of Johannesburg for ease of access (BPCSA 1972:454). This indicated a desire to have ongoing physical contact between the two denominations.

The following year, Rev Douglas Bax moved a notice of motion, in the PCSA General Assembly which was meant to 
allay the fears of the BPCSA, regarding his perception of fears concerning union with a white denomination (PCSA 1973):

We understand the hesitations those who fear that even in a united church the White members will show prejudice and discrimination against, or paternalism towards, the Black members. We understand the doubts of those who fear that the White members will assume an automatic right to all the real power in a united Church and refuse to share it fairly with Black members.

We confess that there is ground for these fears because our Church and we who are White in it have not been free of them because of faults in the past. (pp. 65-66)

This motion emanated from one of the most politically radical voices in the PCSA. It was paternalistic and devoid of any repentance. As sensitive as it seemed, it simply reiterated the status quo. When the notice of motion was debated, it was agreed to 'pass from the matter' (PCSA 1973:80-81). This indicated that the PCSA had little regard for its own black members, let alone those of other denominations.

Notable in this commitment was the confession of a lack of evidence of a commitment to racial unity and the need to give greater attention to matters of justice and peace, especially the resolution of racial difference as prerequisites for union. De Gruchy writing in 1979 (1979:96) explains the ethos of the CEO well. They had (De Gruchy 1979):

$[L]$ ittle historical awareness, and an individualism which has lost the ruggedness

of settlers and pioneers, a morality that is either secular and materialistic or

pietist and escapist. ... they are inadequate to the contemporary crisis, and no

match against other strong ideological options It is this situation which calls for

a rediscovery of prophetic elements within the tradition of the English-speaking

churches, a tradition that has often been maintained by people who have become despondent about the apathy of the churches and have left them in order to join the struggle for human rights. (p. 96)

This contrasted rather uncomfortably with the communal identity and lifestyle of black church members for whom struggle was not a choice but a way of living.

A little later in 1973, the BPCSA agreed to discharge its Presbyterian Negotiations Committee as its work was complete and ' $[t]$ hat the Basis of Union negotiations discussions between the Presbyterian churches be kept an open possibility before the three churches' (BPCSA 1973:19). With regard to the CUC union negotiations, it was decided to withhold a response until all presbyteries had responded (BPCSA 1973:40). Progress was slow and no advance was made in 1974. Clearly, there was no sense of urgency in the face of the political exigencies of the time. Union was simply not a priority for black churches.
In 1975, General Assembly agreed to remit the 'Scheme of Union' to presbyteries for ratification (BPCSA 1975:35). On another front, however, progress was made when the Business Committee approved the merger of the Congregational Adams College with the Presbyterian St Columba's College at the Federal Theological Seminary of Southern Africa to form a Reformed Albert Luthuli College (BPCSA 1975:44). These two colleges had worked side by side along with the Methodist John Wesley and Anglican St Peter's colleges since 1960, and this was considered to be a natural practical and ecumenical progression. Prior to this, the Congregational, Methodist and Presbyterian churches were involved in the establishment of a Faculty of Divinity at Rhodes University in 1947 for the training of white candidates for their ministry (De Gruchy 1999:158-159). These ecumenical projects went some way to bringing about a sense of common purpose among ministers in training.

'The First Draft of the constitution of the United Church in Southern Africa (Presbyterian/Congregational)' was sent down to Presbyteries and the Assembly resolved that if the Scheme of Union was accepted 'to negotiate with the churches which have accepted' it (BPCSA 1976:33). This referred to the TPC and the UCCSA. The Assembly was in favour of organic union and rejected any federal scheme. However, while the PCSA appeared to be in favour of union, it was noted that 'the Church as a whole is not entirely in favour of union' (PCSA 1980:70). Yet, it was also noted that 'not one of the arguments raised against union has focussed on a major theological difference'. Interestingly, it was further noted that 'there are more theological differences within the PCSA than there are between the PCSA and the other three denominations in the union negotiations'. For instance, the issue of infant and believer's baptism was an internal controversial problem. Hence, the reasons had to be more localised - 'structural and financial concerns' (PCSA 1980:72). This hesitancy was because of the PCSA being well aware that union implied that the united church would have a black majority, and this implied further that the black majority would be financially dependent on the white minority. This was not the case with the BPCSA for all of its congregations were self-supporting and had no white constituency to bail them out when in financial difficulties.

No further significant movement took place until 1982 when it became evident that there was no clear commitment to unity on the part of the RPCSA. However, the Assembly decided to establish a committee with a specific mandate:

1. to formulate a strategy for continuing with the search [for unity]

2. to open negotiations with the black churches of the Reformed family as a first stage in the fulfilment of the strategy

3. to monitor matters relating to Church Union

4. to report to the Assembly. (RPCSA 1982:23)

While the General Assembly still appeared to be committed to organic unity, it was clear that this enthusiasm was not shared at presbytery and congregational level. This was 
partly because of the intensifying political situation and continuing distrust of white Presbyterians. Survival had become a greater priority than ecumenism and hence the move to negotiate, in the first instance, with black Reformed sister churches where there was a clear sense of solidarity in the struggle.

The outcome of the RPCSA Assembly decision (RPCSA 1982:23) was the formation of the Ecumenical Relations Committee (ERC) which was to oversee all developments in the sphere of ecumenical relations.

This aimed to produce a more coherent approach to ecumenism. The first term of reference was 'To promote, foster and maintain good fraternal relations between the Reformed Presbyterian Church and other denominations of the Universal Church of Jesus Christ' (RPCSA 1988:56). It placed no limitation on who it would negotiate with. The ERC report in 1985 (RPCSA 1985:30) showed part of the extent of national and international ecumenical relations which included the CUC, the South African Council of Churches, the All Africa Council of Churches, the World Council of Churches, the Alliance of Black Reformed Christians in South Africa (ABRECSA) and the Church of Scotland, as well as the denominations with which the BPCSA was in union negotiations. De Gruchy (2005:124) is correct in his opinion that 'It is difficult to overestimate the significance of these longstanding and extensive ecumenical relationships for the struggle of the church in South Africa'. Yet, serious tensions arose in 1968 when the World Council initiated its Programme to combat racism which caused great tension within the multi-racial churches and between them and the black churches. Despite this, his assertion is correct for great benefits were derived from the support of the church universal in terms of morale.

At the local level, issues reappeared between the BPCSA and the PCSA regarding interference in its congregations which led to a complaint being lodged with the PCSA concerning 'repeated pastoral interference' at Ulundi in addition to attempts 'to resolve outstanding problems' with the PCSA (RPCSA 1985:30). This indicated the reappearance of an old issue which disturbed fraternal relations. By this time, negotiations had been entered into with the Evangelical Presbyterian Church (EPCSA) (RPCSA 1984:30).

In the PCSA, by 1982, opposition to union had grown considerably, although it was agreed to proceed with negotiations (PCSA 1982:235). The issue was that there appeared to be a lack of knowledge and understanding of the thinking behind the move towards union (PCSA 1982:235, 236). The General Assembly Moderator, the Rt Rev LA Maart, was charged with providing a sounding board for those with concerns regarding union. He reported a number of issues in 1983. He recommended 'to the church that it should suspend the present programme until the 1986 General Assembly when a decision can be made' (PCSA 1983:184). This was agreed (PCSA 1989).
The PCSA described the progress of union negotiations from 1959 until 1984 as follows:

From 1959 onwards there were union negotiations involving the PCSA, the BPC and the Tsonga Presbyterian Church (which arose out of the work of the Swiss Mission in South Africa and is now called the Evangelical Presbyterian Church). The BPC was not able to muster enough support for the union and withdrew from the negotiations in 1972. The following year negotiations were restarted this time involving the United Congregational Church of Southern Africa as well. These followed a complicated course with strong feelings being aroused in the PCSA. In 1981 the RPC withdrew from the negotiations and the EPC opted for observer status only. The PCSA and UCCSA continued until 1984, when a majority of our Presbyteries turned down the Plan of Union. (p. 41)

As can be seen, during this period relations with the PCSA reached an all-time low except for an attempt by the PCSA Moderator of General Assembly, the Rt Rev Glen Craig, a strong advocate of union, to reopen discussions (PCSA 1987:76). But there was no unanimity even in the PCSA.

By 1987, the RPCSA Assembly noted a draft constitution for union with the EPC and 'declare[d]that the Reformed Presbyterian Church is now ready on its basis to unite with the Evangelical Presbyterian Church' (RPCSA 1987:25). In 1988, the ERC reported with regard to union with the EPC that it was 'not able to report progress this year' and reaffirmed its decision to unite. In fact, the EPC had withdrawn largely because of impending problems arising from its close relationship with the Gazankulu homeland government, but they did not feel free to communicate this to the RPCSA officially. Its first lay Moderator, Prof. HWE Ntsanwisi (1959-1971), was also the first leader of the Gazankulu homeland; its General Secretary, Rev JS Shimate, was the Minister of the Interior, and his successor, Rev Sydney Ngobe, was a member of the Gazankulu Development Corporation (Halala et al. 2015:113, 119, 120-121). Part of the issue for the EPC was its internal divisions which arose with the establishment of the Standing for the Truth (SFT) movement which divided the supporters of the Gazankulu homeland and those who were opposed 'to the involvement of the Church in the politics and administration of the homeland government' (Halala et al. 2015:125). This arose as the result of ecumenism for the dispute was primarily between this who have been trained at the politically aware Fedsem and those trained in the more conservative context of Lesotho, who were loyal to the homeland. The early leaders of the SFT were Rev Dr Jean-Francois Bill, Rev Prof. Tinyiko Maluleke and Rev Michael Nyawo. 'Several attempts were made to reconcile the two sides, but it was to no avail' (Halala et al. 2015:130). Despite offers to continue negotiations, the EPCSA failed to respond.

There was no advance by the time of the 1989 or the 1992 General Assemblies (RPCSA 1992:45). A meeting was scheduled with the PCSA with the prayer 'that the Holy Spirit will guide them into all truth in dealing with the issues that have hindered proper relations between our two sister 
Churches' (RPCSA 1989:35). Preliminary meetings led to a Basis of Agreement that both denominations should make a fresh beginning by focussing on past failures, long-term relationships and a commitment to greater cooperation (PCSA1990:18). It is interesting to note that 'the Presbyterian Black Leadership Consultation was asked to spearhead the implementation of the Agreement' (PCSA 1991:22) with the black RPCSA to fulfil its 'commitment to the rebuilding of trust and fellowship and cooperation, [as] a living reality' rather than organic union at this stage (PCSA1992:127). This can be described as black-on-black ecumenism. However, it was conscious of the immensity of the task in the prevailing climate politically marked by (PCSA 1992):

Callous and cynical violence, revelations of corruption and theft of the nation's assets on a vast scale, the politics of accusation, threat and manipulation. Is this not the time when the Church is called, even more urgently than before, to demonstrate the real meaning of reconciliation? (p. 127)

However, how could reconciliation even be considered following the imposition of successive states of emergency during the 1980s and the intensification of violence? Actions were needed to corroborate the desire for reconciliation if it were a possibility. The release of Nelson Mandela from long-term detention was, at least, a symbolic gesture in the direction of significant potential and far-reaching change.

By 1995, and the arrival of democracy, interest in union with the PCSA was again on the agenda. Following the transition to a democratic South African society in 1994, the black RPCSA was able to exhibit a greater confidence and generosity in union talks. It offered to re-enter union discussions with the PCSA.

By the 1996 General Assembly, union negotiations between the PCSA and the RPCSA had taken a more serious and positive turn. The 1997 General Assembly approved the Basis of Union (RPCSA 1997:51). The final resolution was passed in 1998 to unite with the PCSA (RPCSA 1998:147) and was sent down to Presbyteries under the Barrier Act, which is a necessary procedure when matters of considerable substance presaging significant change are being considered (RPCSA 1997:51). It was agreed to delay the date of the union in order for the PCSA to celebrate its centenary in 1997, although this would have been a good date on which to celebrate the union between the RPCSA and the PCSA, a union which had failed 100 years earlier. The principle of union was agreed and a Special Commission was appointed to prepare for union. Its first priority was to clarify the historic issues which had distanced the two denominations from one another. This was a testing exercise for those involved for some of these issues have a lengthy history and had caused deep hurt and anger. The Basis of Union was adopted by the RPCSA in 1997. The 1998 General Assembly, taking account of returns from presbyteries and after a vigorous discussion, voted in favour of union (RPCSA 1998:57). The PCSA had already voted in favour of union (RPCSA 1998:147). A Special Committee on
Union was appointed to carry the process through. Co-chairs were appointed in the persons of Rev Prof MJ Masango and Rev DM Soga representing the two denominations (PCSA 1999:21) with a number of committees.

There followed an intense and difficult year of negotiation in which some policies were agreed and others held over until the post-union period. Most of the disagreements centred on administrative and logistical matters - the location of the General Assembly office, staffing, time and place of General Assembly. The two approaches to theological education were especially divisive (PCSA 1999:32-33, 66, 67-69). It was agreed to use the Manual of Law, Practice and Procedure of the PCSA until it could be modified into an Interim Manual. The land and property issue was resolved by the PCSA agreeing that all its immovable assets being transferred to the UPCSA while no action was agreed regarding the immovable properties still held by congregations (PCSA 1999:23; RPCSA 1999:28). The union took place in Port Elizabeth on 26 September 1999.

Sadly, the union did not include the EPCSA, the PCA and the United Congregational Church of South Africa (UCCSA). With regard to the latter, conversation had taken place sporadically throughout the 20th century, but without success (De Gruchy 2009:29).

\section{Conclusion}

The period from 1940 until 1999 was fraught with difficulties for the two Presbyterian denominations which united in 1999 and other churches of European origin which also negotiated with them. Throughout this period, the shadow of racism and then institutionalised apartheid was constantly present in the background, if not in the forefront, as a challenge to their mutual (lack of) trust, integrity and sense of ecumenism. The good faith of all the participants was affirmed throughout the process. In some sense, it is difficult to understand how the Uniting Presbyterian Church of Southern Africa could have been established without passing through the purifying fire of 1994. This gave the RPCSA courage to approach the PCSA on an equal footing, while earlier it had been in the position of the underdog responding to pressure from the PCSA. So, in some way, it was the result of political change. What is unfortunate is that the union did not include the EPCSA, the PCA and the UCCSA, the denominations with whom the uniting churches had been in conversation at intervals over the years, not to mention the Methodist and Anglican churches of the CUC.

\section{Acknowledgements Competing interests}

The author has declared that no competing interests exist.

\section{Authors' contributions}

G.A.D. is the sole author of this article. 


\section{Ethical considerations}

This article followed all ethical standards for carrying out research without direct contact with human or animal subjects.

\section{Funding information}

This research received no specific grant from any funding agency in the public, commercial or not-for-profit sectors

\section{Data availability statement}

Data sharing is not applicable to this article as no new data were created or analysed in this study.

\section{Disclaimer}

The views and opinions expressed in this article are those of the author and do not necessarily reflect the official policy or position of any affiliated agency of the author.

\section{References}

Bantu Presbyterian Church of South Africa (BPCSA), 1942, Proceedings of Genera Assembly, BPCSA, Umthatha.

Bantu Presbyterian Church of South Africa (BPCSA), 1944, Proceedings of General Assembly, BPCSA, Umthatha.

Bantu Presbyterian Church of South Africa (BPCSA), 1956, Proceedings of General Assembly, BPCSA, Umthatha.

Bantu Presbyterian Church of South Africa (BPCSA), 1958, Proceedings of General Assembly, BPCSA, Umthatha.

Bantu Presbyterian Church of South Africa (BPCSA), 1959, Proceedings of General Assembly, BPCSA, Umthatha.

Bantu Presbyterian Church of South Africa (BPCSA), 1960, Proceedings of General Assembly, BPCSA, Umthatha.

Bantu Presbyterian Church of South Africa (BPCSA), 1964, Proceedings of General Assembly, BPCSA, Umthatha.

Bantu Presbyterian Church of South Africa (BPCSA), 1965, Proceedings of Genera Assembly, BPCSA, Umthatha.

Bantu Presbyterian Church of South Africa (BPCSA), 1966, Proceedings of General Assembly, BPCSA, Umthatha.

Bantu Presbyterian Church of South Africa (BPCSA), 1967, Proceedings of General Assembly, BPCSA, Umthatha.

Bantu Presbyterian Church of South Africa (BPCSA), 1968, Proceedings of General Assembly, BPCSA, Umthatha.

Bantu Presbyterian Church of South Africa (BPCSA), 1969, Proceedings of General Assembly, BPCSA, Umthatha.

Bantu Presbyterian Church of South Africa (BPCSA), 1970, Proceedings of General Assembly, BPCSA, Umthatha.

Bantu Presbyterian Church of South Africa (BPCSA), 1971, Proceedings of General Assembly, BPCSA, Umthatha.

Bantu Presbyterian Church of South Africa (BPCSA), 1972, Proceedings of General Assembly, BPCSA, Umthatha.

Bantu Presbyterian Church of South Africa (BPCSA), 1973, Proceedings of General Assembly, BPCSA, Umthatha.

Bantu Presbyterian Church of South Africa (BPCSA), 1975, Proceedings of General Assembly, BPCSA, Umthatha.

Bantu Presbyterian Church of South Africa (BPCSA), 1976, Proceedings of General Assembly, BPCSA, Umthatha.
Best, T., 1992, Living today towards visible unity: Faith and Order paper no. 142, Geneva World Council of Churches.

De Gruchy, J.W., 1979, The church struggle in South Africa, David Philip, Cape Town.

De Gruchy, J.W., 1997, 'Grappling with a colonial heritage: The English-speaking churches under apartheid', in R. Elphick \& R. Davenport (eds.), Christianity in South Africa: A political, social and cultural history, pp. 155-172, David Philip, Cape Town.

De Gruchy, J.W., 2009, Christianity and the modernisation of South Africa: A documentary history, vol. 2, UNISA Press, Pretoria.

De Gruchy, J.W. \& De Gruchy, S., 2005, The church struggle in South Africa: 25th anniversary edition, Fortress, Minneapolis, MN.

Duncan, G.A., 2017, 'The Bantu Presbyterian Church in South Africa and Ecumenism, 1923-1939', Studia Historiae Ecclesiasticae 43(3), 16 pages. https://doi. org/10.25159/2412-4265/2896

Duncan, G.A., 2018, 'To unite or not to unite? That is the question: A case study of Presbyterianism in South Africa, 1897-1923', Acta Theologica 38(1), 37-60. https://doi.org/10.18820/23099089/actat.v38i1.3.

Halala, P., Khosa, M.W., Makaana, J., Masangu, H.D., Nwamilorho, J. \& Tshwane, J., 2015 A history of the Evangelical Church in South Africa, 1875-2015, P \& H Publishers, Tzaneen.

Presbyterian Church of South(ern) Africa (PCSA), 1959, Papers and proceedings of General Assembly, PCSA, Johannesburg.

Presbyterian Church of South(ern) Africa (PCSA), 1962, Papers and proceedings of General Assembly, PCSA, Johannesburg.

Presbyterian Church of South(ern) Africa (PCSA), 1965, Papers and proceedings of General Assembly, PCSA, Johannesburg.

Presbyterian Church of South(ern) Africa (PCSA), 1970, Papers and proceedings of General Assembly, PCSA, Johannesburg.

Presbyterian Church of South(ern) Africa (PCSA), 1973, Papers and proceedings of General Assembly, PCSA, Johannesburg.

Presbyterian Church of South(ern) Africa (PCSA), 1980, Papers and proceedings of General Assembly, PCSA, Johannesburg.

Presbyterian Church of South(ern) Africa (PCSA), 1982, Papers and proceedings of General Assembly, PCSA, Johannesburg.

Presbyterian Church of South(ern) Africa (PCSA), 1983, Papers and proceedings of General Assembly, PCSA, Johannesburg.

Presbyterian Church of South(ern) Africa (PCSA), 1989, Papers and proceedings of General Assembly, PCSA, Johannesburg.

Presbyterian Church of South(ern) Africa (PCSA), 1990, Papers and proceedings of General Assembly, PCSA, Johannesburg.

Presbyterian Church of South(ern) Africa (PCSA), 1999, Papers and proceedings of General Assembly, PCSA, Johannesburg.

Reformed Presbyterian Church of Southern Africa (RPCSA), 1982, Proceedings of General Assembly, BPCSA, Umthatha.

Reformed Presbyterian Church of Southern Africa (RPCSA), 1985, Proceedings of General Assembly, BPCSA, Umthatha.

Reformed Presbyterian Church of Southern Africa (RPCSA), 1987, Proceedings of General Assembly, BPCSA, Umthatha.

Reformed Presbyterian Church of Southern Africa (RPCSA), 1988, Proceedings of General Assembly, BPCSA, Umthatha.

Reformed Presbyterian Church of Southern Africa (RPCSA), 1989, Proceedings of General Assembly, BPCSA, Umthatha.

Reformed Presbyterian Church of Southern Africa (RPCSA), 1992, Proceedings of General Assembly, BPCSA, Umthatha.

Reformed Presbyterian Church of Southern Africa (RPCSA), 1997, Proceedings of General Assembly, BPCSA, Umthatha.

Reformed Presbyterian Church of Southern Africa (RPCSA), 1998, Proceedings of General Assembly, BPCSA, Umthatha.

Reformed Presbyterian Church of Southern Africa (RPCSA), 1999, Proceedings of General Assembly, BPCSA, Umthatha.

Villa-Vicencio, C., 1988, Trapped in apartheid: A socio-theological history of the English-speaking churches, Orbis, Maryknoll.

Wing, J., 1990, 'An outline of the search for union in South Africa', In Touch 2(18), 1-17.

Xapile, S.P., 1999, 'Unity between the Bantu Presbyterian Church and the Presbyterian Church of Southern Africa, 1959-1971', MA dissertation, University of Cape Town, Cape Town. 